\title{
Experience of construction of deep ditches for underground constructions in weak soils Saint-Petersburg
}

\author{
R. Mangushev ${ }^{\text {i) }}$, E. Lashkova ${ }^{\text {ii) }}$ and V. Smolenkov ${ }^{\text {iii) }}$ \\ i)Professor, Head of Geotechnical Department, St.Petersburg State Civil Engineering University, 4, the 2nd Krasnoarmeyskaya ul., \\ St.Petersburg, 190005, Russia. \\ ii) Director General, GEOIZOL Co.Ltd, 25/2,build E, Bolshoy pr., St.Petersburg, 197198, Russia. \\ iii) The First Deputy of Director General, GEOIZOL Co.Ltd, 25/2,build E, Bolshoy pr., St.Petersburg, 197198, Russia.
}

\begin{abstract}
The information about the engineering-geological conditions in the central part of St. Petersburg which are characterized by deep thickness of weak water saturated soil is given. Three buildings with large underground space constructed in St. Petersburg are considered as examples. The depth of each space exceeds $12 \mathrm{~m}$ and required the usage of modern and nonstandard construction and technological methods for protection of the ditch walls. The wall protection was done by sheet piles, by diaphragm wall method, and jet grouting method. The soil excavation was carried out by traditional method or top-down method. The basic constructive schemes and technological methods of ditch excavation, test results of deformation of the protection walls during excavation of the ditch and the settlements of the neighboring buildings are given.
\end{abstract}

Keywords: soft soils, deep excavation, underground constructions, diaphragm wall, top-down method

\section{INTRODUCTION}

The development of the modern City is not possible without the development of underground space. But the construction conditions in St. Petersburg are much more complicated than in any other region of the country. Mainly this is explained by specific geological conditions - the central part of the City is located on weak, water saturated thixotropic soil, which change their properties depending on the effect of different forces - natural and technogenic.

Generally, the total thickness of the lacustrine-and-marine deposits does not exceed $5 \mathrm{~m}$. They are represented by silty sands, sandy loams and loams. In their layers, there might be lenses and bands of peat and peaty soils of various composition. These soils have comparatively high and non-uniform compressibility.

The lacustrine-and-glacial deposits - clays, loams and sandy loams - are practically pervasive and have stratified or ribbon structure, which determines a number of their specific properties. These soils are characterized by high natural moisture content and porosity, anisotropism of mechanical properties, high compressibility, heaving properties and thixotropy.

Biogenic deposits in the form of peat, peaty soil and soils admixed with vegetable remains occur as surface layers and lenses 1 to $3 \mathrm{~m}$ thick and sometimes even thicker. In the old development districts, there are areas that are formed by peat buried under of reclaimed and filled soils of various comnposition.

Primary deposits are represented, for the most part, by Proterozoic, Paleozoic and Ordovician deposits.

Most of the buildings which were constructed in 18-19 centuries or beginning and middle of 20-th century have cracks and damages of the bearing structures and require the reinforcement of their base and foundations (Mangushev, 2004).

Any additional settlement of such buildings during ditch excavation by traditional method (pile sheet wall, soil excavation, lowering of ground waters by open excavation and etc.) may cause unpredictable result.

The construction in St. Petersburg require high professionalism starting with projecting work when you choose the method of supporting the wall of the ditch and the technology of the future work. The availability of the modern equipment for underground work and qualified personnel is of great importance. The examples of the construction of three modern buildings with large underground space in St. Petersburg are given in the present article.

\section{FIVE LEVEL UNDERGROUND PARKING ON KOMENDANTSKAYA SQUARE.GENERAL SPECIFICATIONS}

In 2006 GEOIZOL company made the project and started construction of the circular 5 level underground parking on Komendantskaya Square. The depth reached $19,5 \mathrm{~m}$ and the diameter $78 \mathrm{~m}$. The general cross 
section is shown in Fig. 1.

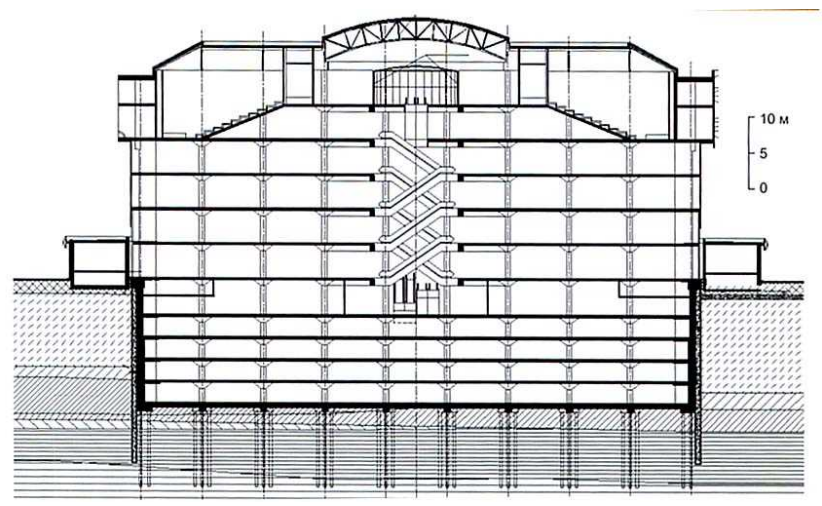

Fig 1. The general cross section of the building

The main problems which appeared during the construction were the absence of the experience in the construction of such types of buildings in St. Petersburg and complicated geological conditions (thixotropic soil in the upper part of the geological section, high level of ground waters and presence of big boulders).

Since the parking with such spacious underground room was constructed in newly developing region it was possible to dispose it at the distance of $100 \mathrm{~m}$ from the nearest buildings. This allowed to ignore the effect of the parking on neighboring buildings.

The technical solution of the erection of the underground part of the building suggested:

1. Initial trench made by diaphragm wall method $24 \mathrm{~m}$ deep and $0,8 \mathrm{~m}$ wide which was filled cement-clay solution (Fig. 2). The ground was excavated by portions $3,3 \mathrm{~m}$ long each.

2. Immersion of the metal semicircular sheet pile into the trench and its subsequent concreting (Fig. 2). Sheet pile served as a reinforcing element and additional seal.

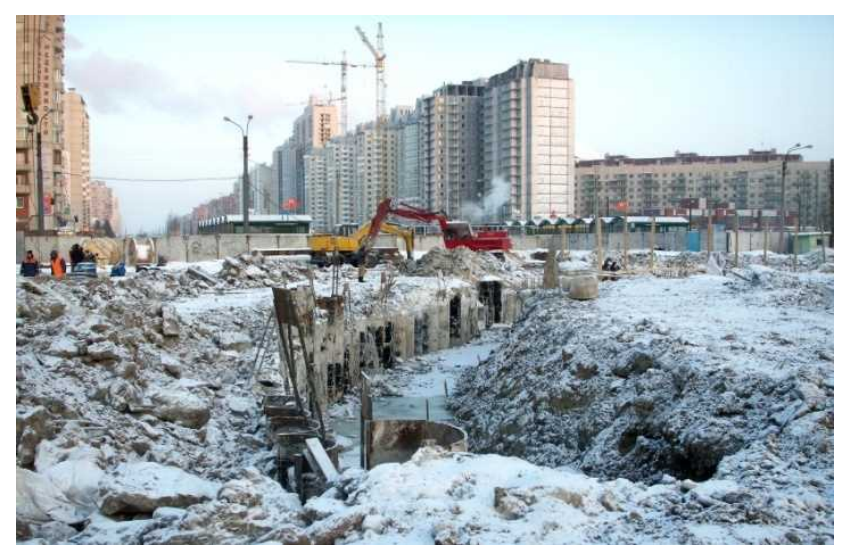

Fig. 2. Initial trench made by diaphragm wall method and sheet pile immersion

3. Erection of monolith concrete beams which served as stiffening ribs and excavation of the ditch by portions while making monolith walls and parts of beam ceiling (Fig. 3).

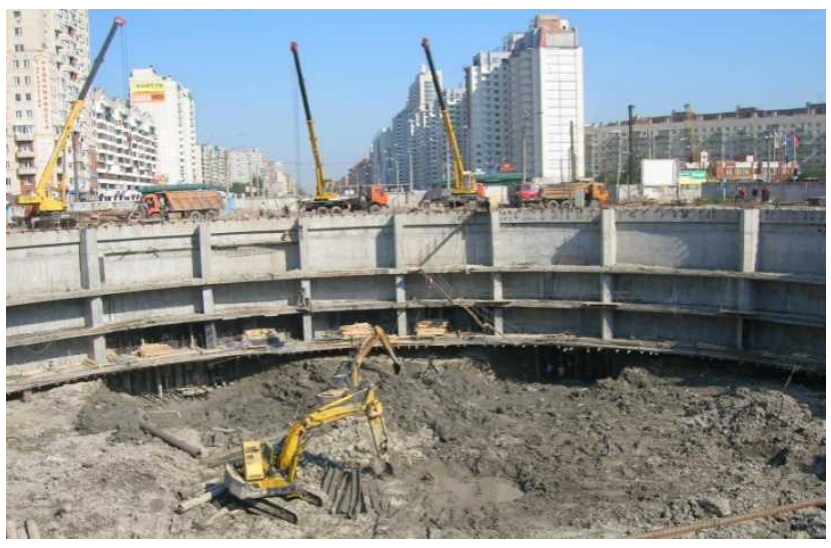

Fig. 3. The beams, parts of ceiling and excavation of the ditch level by level

4. The erection of 290 anchor borrow concrete piles $12 \mathrm{~m}$ long section $250 \mathrm{~mm}$ and concreting the reinforced concrete plate on the level - $18 \mathrm{~m}$ (Fig 4).

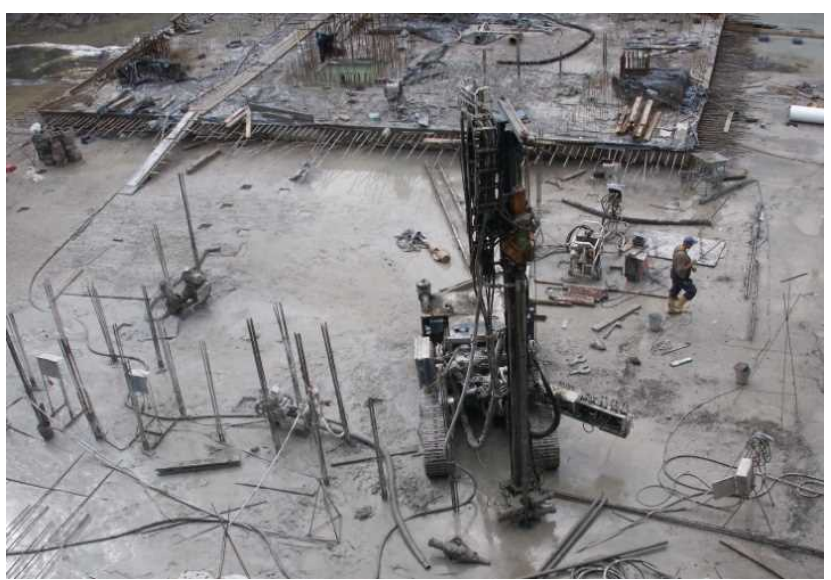

Fig. 4. Anchor piles and monolith reinforced concrete bottom plate

There was no influx of the water from outside of the wall since the diaphragm wall reached the dense undisturbed Cambrian clay.

In order to avoid the floating up of the bottom of the structure under the pressure of hydrostatic force, the reinforcement of anchor borrow concrete piles was connected with the reinforcement of the lower plate. This allowed to make united anchor system.

The horizontal movement of the circular walls during the ditch excavation was checked with the help of inclinometers. Inclinometers were immersed into the earlier installed plastic tubes along the whole height of the diaphragm wall. The horizontal movement of walls of underground structure during excavation within certain period of time is shown in diagram (Fig 5). 


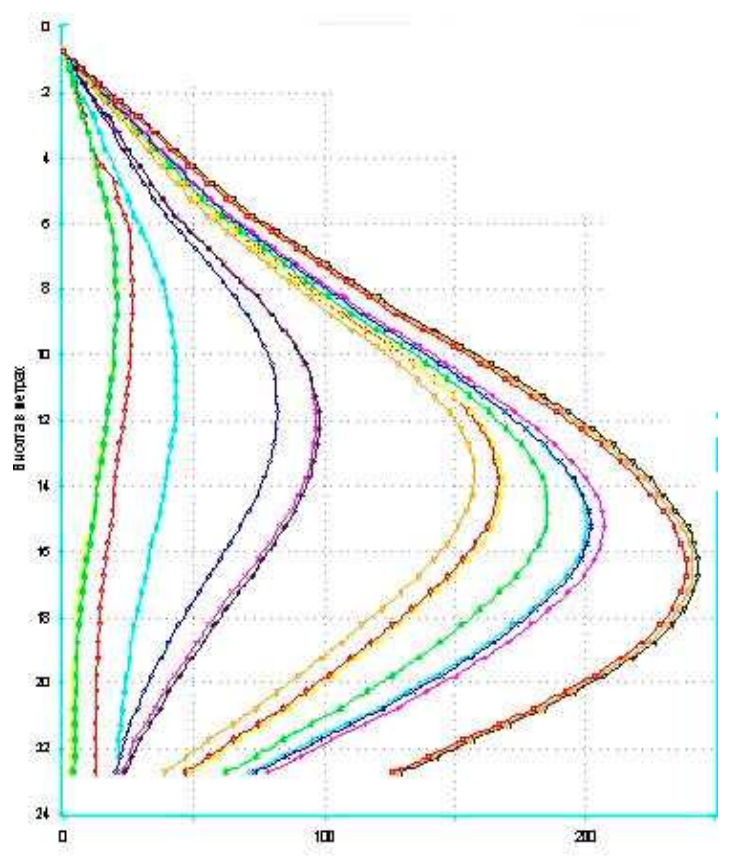

Fig. 5. Example of the horizontal movements of walls of underground structure within certain period of time

The maximal measured movement of the wall into the ditch was $250 \mathrm{~mm}$ and happened at the depth of 15 meters. A t the end of 2008 the building was put into operation (Fig. 6).

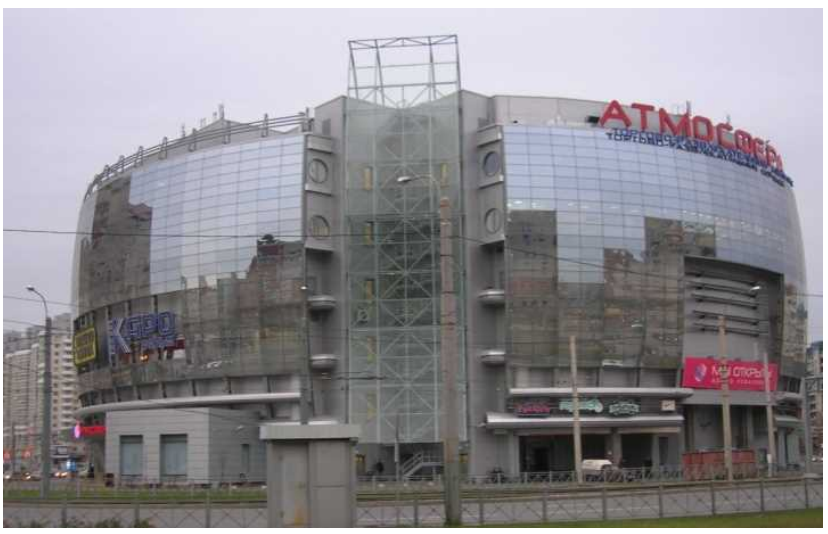

Fig. 6. General view of the building with 4 level parking

\section{THE UNDERGROUND PART IN STOCKMANN TRADE CENTER}

In 2007 the construction of the new Stockmann Trade Center was started in the center of the city on the corner of Nevsky Prospect and Vosstaniya str. The building has 3-4 level underground space 15 meters deep in the form of trapezium (the base is $60 \mathrm{~m}$ the height of one of the sides 130m) (Fig. 7).

On 2 sides of the construction site there were neighboring buildings. As a protective structure of the underground part the initial project suggested the metal sheet pile Larcen V $25 \mathrm{~m}$ long which was immersed by vibro immerser of high frequency.
The experience received in St. Petersburg showed that this method of immersing the sheet pile into unstable soil could result in the settlement of the neighboring buildings and exceed the allowed value. That is why foundations of the buildings along Nevsky Prospect were reinforced by piles Titan prior the excavation of the ditch. The piles were tested against 70 ton vertical loading.

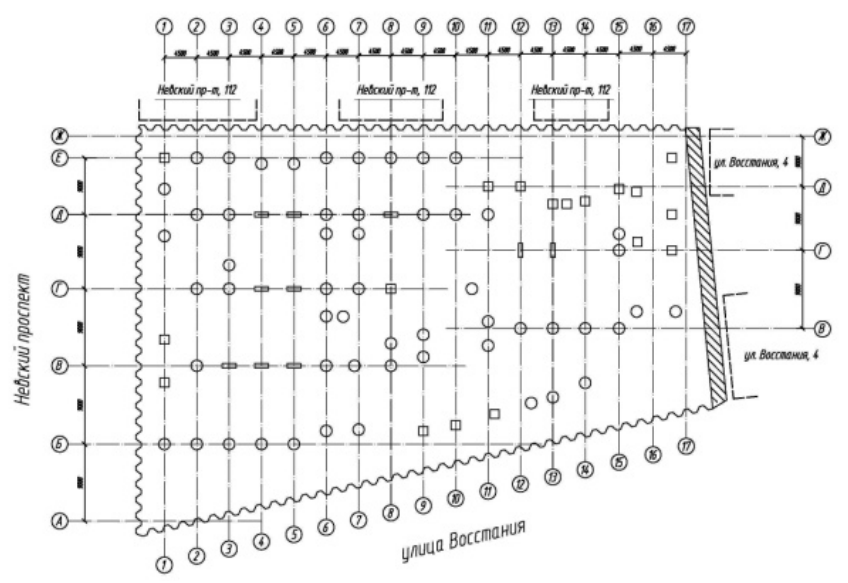

Fig. 7. Scheme of the underground part of the Trade Center

Since the Client failed to agree with the owner of the building along Vosstaniya Str. upon the foundation reinforcement of his building, it was necessary to make the protection wall along one of the sides of the ditch as diaphragm wall instead of pile sheet (Fig 8) (Smolenkov, 2009).

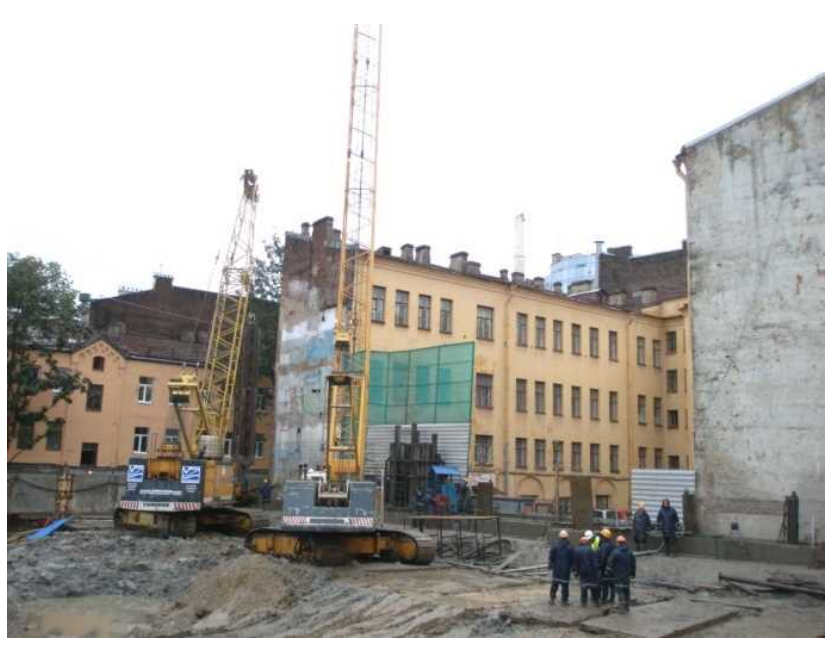

Fig. 8. Diaphragm wall along one of the sides of the ditch.

Though the stiff sheet pile was used along three sides and diaphragm wall along the forth side, the stiffness of the structure was not sufficient due to the weak soil in the construction site. The deformation of the sheet pile below the bottom of the ditch could occur. 
In order to avoid the damaging effect of the new building on the old neighboring buildings and metro station the engineers suggested to fix the lower part of the sheet pile at the depth $17-20 \mathrm{~m}$ by making the soil diaphragm by jet technology (Broid, 2004).

Further development of the underground space was done by top-down method. Some new technical solutions were applied: borrow piles-columns einforced by steel tube and special metal profile and also borrow piles of standard diameter and with expansion in the lower part up to $1300 \mathrm{~mm}$ which supported the ceiling. The length of the piles was $40,8 \mathrm{~m}$.

The ceilings which were put on the ground and under which the soil was later excavated through technological apertures, served as strut elements for protecting the structure. (Fig 9).

After finishing the ceiling on the ground level the construction of the overground elements - columns, walls, ceilings of the upper floors - was started.

All the works on the ground level and further construction of the over ground level did not cause any serious additional settlements of the neighboring buildings, their foundations were earlier reinforced by piles Titan. But the building which was not reinforced in its foundation, received deformation of the bearing structures and required the restoration.

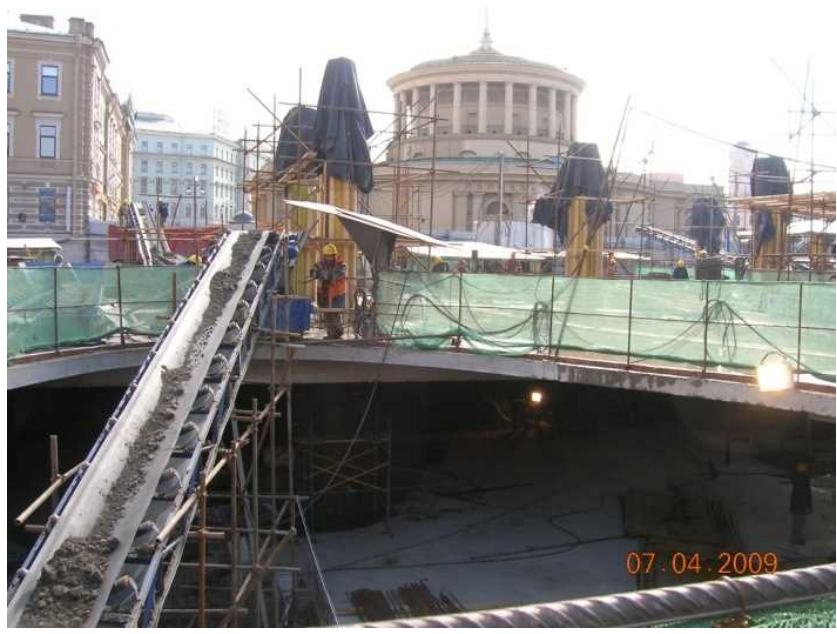

Fig. 9. Excavation of the soil under the ceiling

\section{THE CONSTRUCTION OF THE UNDERGROUND PART OF THE BUILDING FOR THE SECOND STAGE OF MARIINSKY THEATER}

The top-down method was successfully used when constructing the underground space $150 \times 80 \mathrm{~m}$ and 12,5 $\mathrm{m}$ deep for the building of the second stage of Mariinsky theater in St. Petersburg. The building was constructed on soft thixotropic watersaturated soil in the center of the City surrounded by apartment houses (Fig 10).

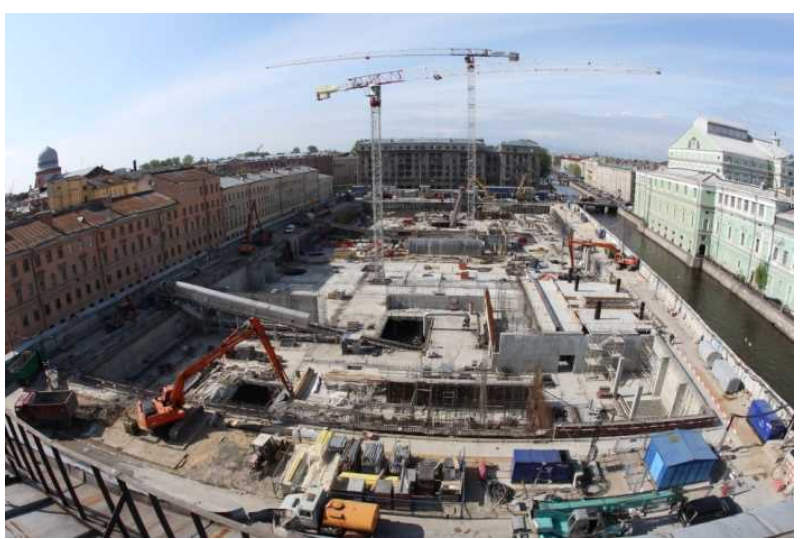

Fig 10. General view of the construction site

The substructure construction and installation works are included the vibration penetration of the $\mathrm{AU}$ Alcelor 18 sheet piling $21 \mathrm{~m}$ long around the excavation pit and the construction of the permanent bored piles from the ground surface. For the future bottom reinforced concrete slab of the facility, the piles 800 to $1200 \mathrm{~mm}$ in diameter were constructed using a casing pipe (Fig. 11) (Mangushev, Ershov, Osokin, 2010).

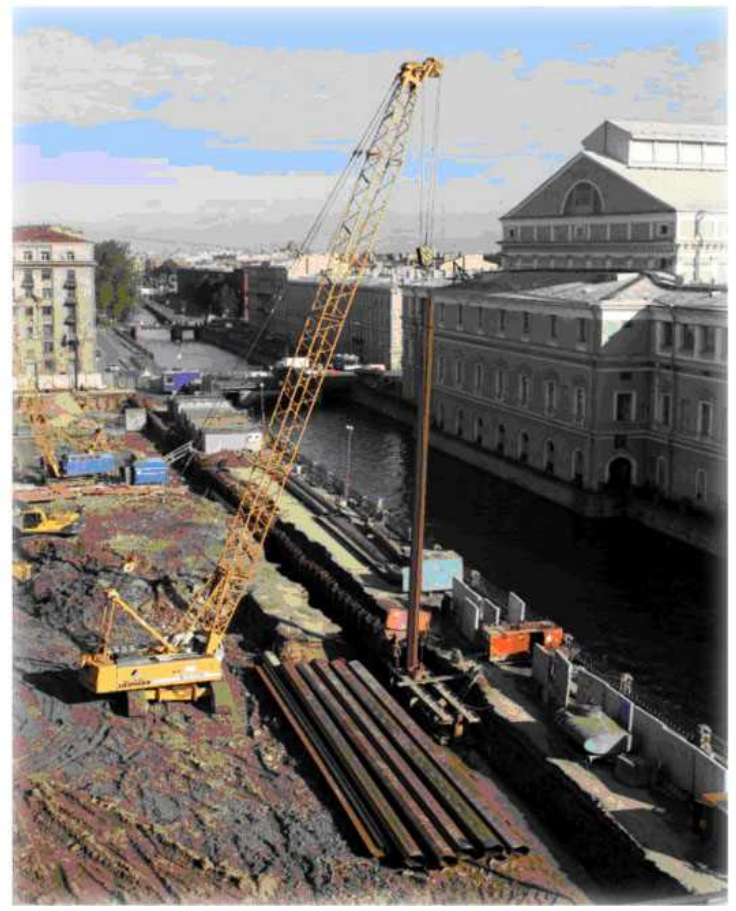

Fug. 11. Lowering of AU Alcelor 18 sheet piling

Due to the destruction of the soil and the development of the settlements in the adjacent buildings during the construction it was necessary to develop a special method of stabilize the soft soil and pit wall reinforcement and further ground excavation from the pit.

The suggested concept of the Mariinsky Second Stage substructure construction included: 
- stabilize the soft soil body by the jet grouting method around the pile sheeting within the area of its maximum horizontal displacements: at the depths of 11,5-14 $\mathrm{m}$ from the ground level (Fig. 12).

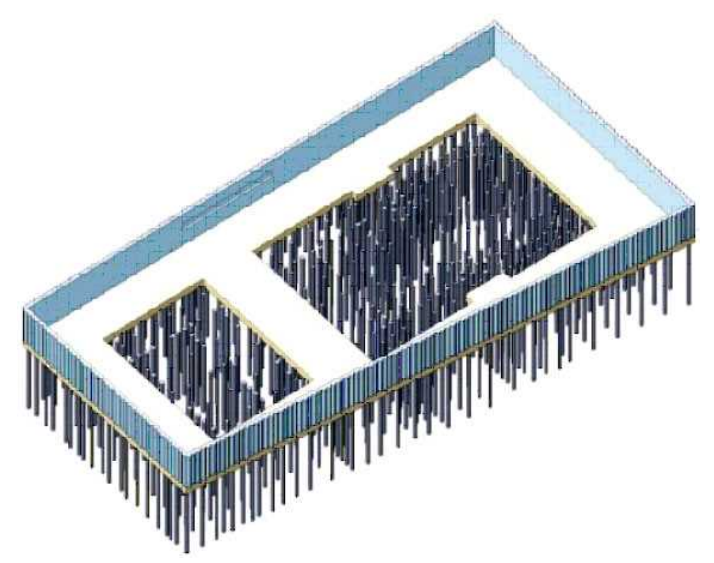

Fig. 12. Schematic view of the completed horizontal diaphragm of soil

- the construction of an additional enclosing vertical diaphragm wall made of tangent soil-cement piles on the external side of the existing pile sheeting. The piles were constructed by the jet grouting method to a depth of $18 \mathrm{~m}$, and the resulted diaphragm wall was reinforced by metal I-beams No. 40 spaced at $1,0 \mathrm{~m}$ (Fig. 13).

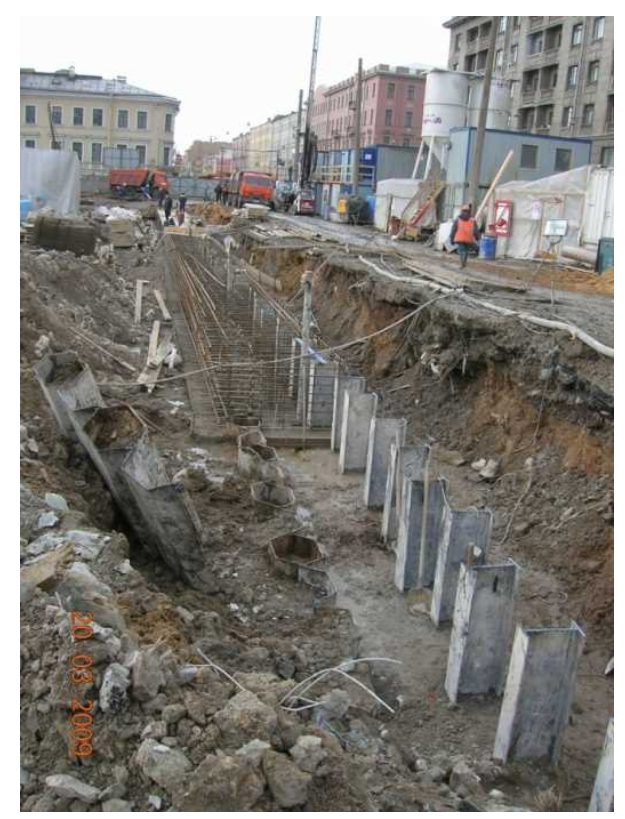

Fig. 13. Construction of the diaphragm wall by jet grouting method on the external side of the pile sheeting and construction of the joining reinforced concrete beam

- the diaphragm wall and sheet piling were joined over their top with a reinforced concrete beam $2,3 \mathrm{~m}$ wide and 1,15 $\mathrm{m}$ high.
- the stage-by-stage pit excavation pit involved the use of the top-down technology, based on which the external sheet piling was strutted with reinforced concrete slabs at Levels $-4,41$ and $-11,1 \mathrm{~m}$ (the top of the slabs) that were constructed as the excavation progresses.

The soil was excavated under this slab using small excavators and removed with conveyors through the preliminarily left technological openings (Fig. 14).

The slab at Level $-4,41 \mathrm{~m}$ is $400 \mathrm{~mm}$ wide and supported by the temporary bored piles $29 \mathrm{~m}$ long, $600 \mathrm{~mm}$ in diameter constructed inside the excavation pit with a mesh of $6 \times 6 \mathrm{~m}$.

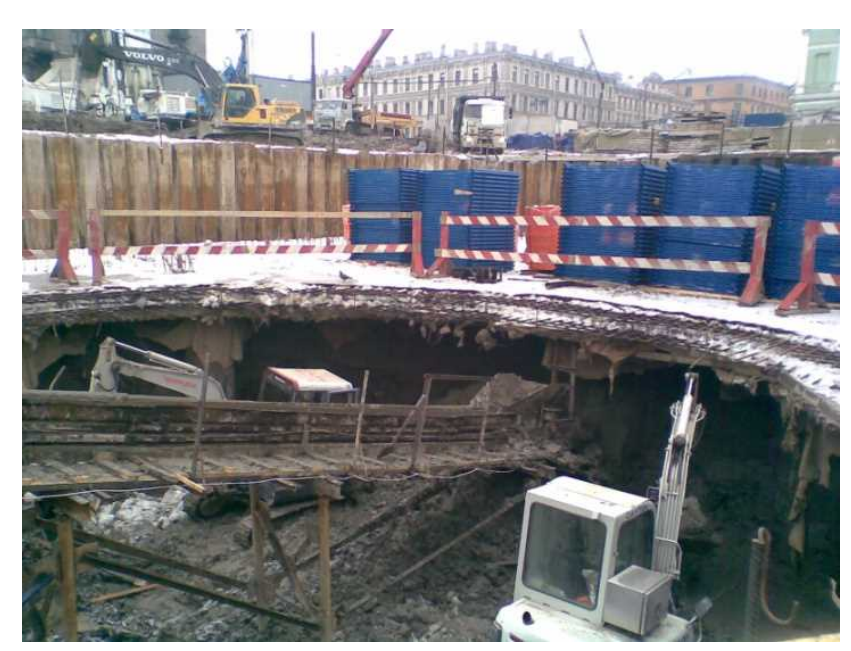

Fig. 14. Soil excavation under reinforced concrete slab below Level 4,0 m

In order to provide the additional rigidity of the sheet piling at Level $-8,11 \mathrm{~m}$, cap beams and sections of the cross walls were constructed. The slab at Level $-11,1 \mathrm{~m}$ is $1200 \mathrm{~mm}$ wide, and its base is a soil-cement diaphragm that was constructed earlier. The reinforcement and the heads of the permanent piles are introduced into the body of the reinforced concrete slab.

Fig. 15 shows a schematic diagram of the excavation of the underground space for the Second Stage Building at one of the technological phases.

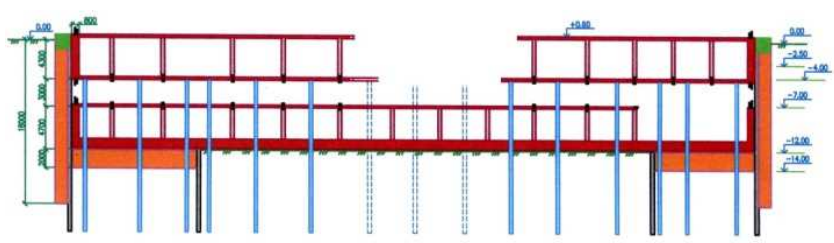

Fig. 15. Structural layout of the underground space excavation: 1 - vertical and horizontal soil-cement diaphragms; 2 - temporary bored piles; 3 - permanent bored piles; 4 - reinforced concrete bottom slab; 5 - reinforced concrete floor slabs; 6 - pile sheeting

When carrying out the above works of all kinds, the regular monitoring was provided for the principal 
structures of the underground facility, as well as for the surrounding buildings and structures.

In the geotechnical justification of the design and in the scientific and technical support, the construction situation was simulated using the dedicated computational software, in particular, the Dutch PLAXIS program in two- and three-dimensional versions (Fig. 16).

When using this software, the FEM characteristics of the foundation soils were taken with consideration for their three-dimensional changes resulted from the technogenic action.

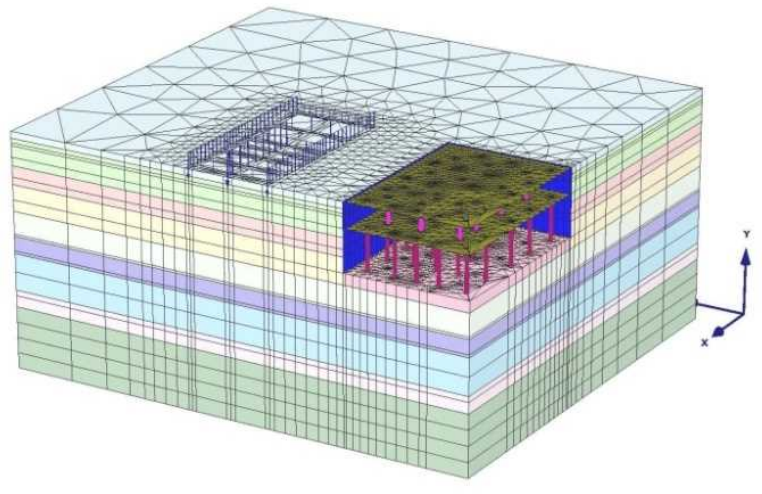

Fig. 16. The computation examples of the underground facility and surrounding buildings using the PLAXIS software three-dimensional scenarios

The strength and deformation properties of the soil were assessed by the cone penetration test method on three sites at multiple points using the movable Swedish cone penetration test equipment GIB 204.

The instrumental measurement showed that, as compared to the non-disturbed values (before the construction commencement), the strength $(\varphi, c)$ and deformation (Eo) soil properties increased approximately by $30 \%$ by means of compacting the soil with the temporary piles and stabilizing it by constructing the horizontal and vertical soil-cement diaphragms constructed by the jet grouting method.

The PLAXIS-based FEM forecast of additional settlements in the surrounding buildings nearest to the excavation pit showed that, when the pit has been completely excavated, the full settlement of the buildings might reach 70 to $80 \mathrm{~mm}$, which exceeds the permissible values for facilities of this category of the technical conditions.

The results of the computational geotechnical justification and the scientific and technical support showed that it was required to prepare measures to underpin the ground beds of the neighboring buildings in case of the their settlement development as the pit excavation progresses.

Before the completion of all works related to the soil excavation inside the underground space near the walls of the buildings in Minsky Street, boreholes were prepared for the compensative slurry injection under the foundation beds.

The settlements of these buildings began at the time of the excavation at the third underground level at the end of May 2009, and in several months, they reached $70 \mathrm{~mm}$ at a number of points. From the time of the active settlement development, it was started the compensative injection of cement-and-sand grout into the previously made boreholes, and by the end of October 2009, it was managed to stop the intensive settlement development (Mangushev R.A., Osokin A.I. (2010).

Upon completion of these works, the facade foundations of the buildings in Minksky Street were transferred onto the Titan piles, which was a guarantee of their further safe operation.

The accepted decisions have allowed to prevent development of an emergency, save the next building and finish the basic construction works of a underground part of the building in 2010.

The second stage of Mariinsky Theatre began to work from May 2013 (Fig.17)

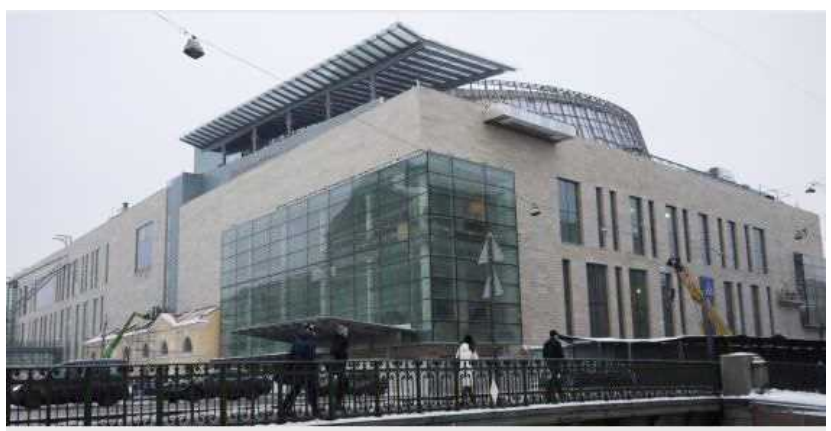

Fig.17. General view of the Second Stage of Mariinsky Theatre

\section{CONCLUSIONS}

The considered examples of these civil buildings in St. Petersburg with large underground space showed that it was possible to make the deep large ditches in soft soil on the condition of proper selection of the rigidity of the protection structure. The choice of these structures is determined by calculations and organizing the test sites.

\section{REFERENCES}

1) Broid I.I. (2004): Jet grouting technology, ASV, Moscow, Russia, $448 \mathrm{pp}$.

2) Mangushev R.A. (2004): The analysis of the constructions of the bases of old buildings in the Centre of St. Petersburg. Soil mechanic and Foundations, Moscow, Russia, 5, 13-16.

3) Mangushev R.A., Ershov A.V., Osokin.A.I. (2010): Newpile technologies, SPBGASU - ASV, St. Petersburg - Moscow, Russia, 160 pp.

4) Mangushev R.A., Osokin A.I. (2010): Geotechnics of St.Petersburg, ASV, Moscow, Russia, $260 \mathrm{pp}$.

5) Smolenkov V.Yu. (2009): GEOIZOL Company`s experience constructions of the underground objects in St. Petersburg. Building construction, Saint-Petersburg, 2, 43-45 